\title{
Exendin-4-Based Radiopharmaceuticals for Glucagonlike Peptide-1 Receptor PET/CT and SPECT/CT
}

Damian Wild ${ }^{1,2}$, Andreas Wicki ${ }^{3}$, Rosalba Mansi ${ }^{4,5}$, Martin Béhé ${ }^{5,6}$, Boris Keil $^{7}$, Peter Bernhardt ${ }^{8}$, Gerhard Christofori $^{3}$, Peter J. Ell ${ }^{2}$, and Helmut R. Mäcke ${ }^{4,5}$

${ }^{1}$ Clinic and Institute of Nuclear Medicine, University Hospital Basel, Basel, Switzerland; ${ }^{2}$ Institute of Nuclear Medicine, University College London, London, United Kingdom; ${ }^{3}$ Institute of Biochemistry and Genetics, Center for Biomedicine, University of Basel, Basel, Switzerland; ${ }^{4}$ Division of Radiological Chemistry, University Hospital Basel, Basel, Switzerland; ${ }^{5}$ Department of Nuclear Medicine, University Hospital Freiburg, Freiburg, Germany; ${ }^{6}$ Department of Nuclear Medicine, Hospital of the Philipps-University, Marburg, Germany; ${ }^{7}$ Department of Radiology, Hospital of the Philipps-University, Marburg, Germany; and ${ }^{8}$ Department of Radiation Physics, University of Gothenburg, Göteborg, Sweden

Strong overexpression of glucagonlike peptide-1 (GLP-1) receptors in human insulinoma provides an attractive target for imaging. The first clinical trials demonstrated that GLP-1 receptor SPECT/CT using [ Lys $^{40}(\mathrm{Ahx}$ [6-aminohexanoic acid]DOTA- $\left.{ }^{111} \mathrm{In}\right) \mathrm{NH}_{2}$ ]-exendin-4 can localize hardly detectable insulinomas. However, [Lys ${ }^{40}\left(\mathrm{Ahx}-\mathrm{DOTA}-{ }^{111} \mathrm{In}\right) \mathrm{NH}_{2}$ ]-exendin-4 imaging has drawbacks related to the use of ${ }^{111} \mathrm{In}$ in that it is costly and carries a relatively high radiation burden for the patient. The aim of this study was the preclinical evaluation of $\left[\mathrm{Lys}^{40}\left(\mathrm{Ahx}-\mathrm{DOTA}-{ }^{68} \mathrm{Ga}\right) \mathrm{NH}_{2}\right]$-exendin-4 for PET/CT and [Lys ${ }^{40}\left(\right.$ Ahx-hydrazinonicotinamide [HYNIC]- $\left.\left.{ }^{99 m} \mathrm{Tc}\right) \mathrm{NH}_{2}\right]$-exendin-4 for SPECT/CT. Methods: Internalization, biodistribution, dosimetry, and imaging studies were performed in the Rip1Tag2 mouse model of pancreatic $\beta$-cell carcinogenesis and compared with our gold standard [Lys ${ }^{40}(\mathrm{Ahx}-$ DOTA- $\left.{ }^{111} \mathrm{In}\right) \mathrm{NH}_{2}$ ]-exendin-4. Poly-glutamic acid and Gelofusine, a gelatin-based plasma expander, were used for renal uptake reduction studies. Results: The tumor uptake of [ $\mathrm{Lys}^{40}(\mathrm{Ahx}-$ DOTA- $\left.{ }^{8} \mathrm{Ga}\right) \mathrm{NH}_{2}$ ]-exendin-4 was $205 \pm 59$ percentage injected activity per gram of tissue at $4 \mathrm{~h}$. Other GLP-1 receptor-positive organs showed more than 4.8 times lower radioactivity uptake. [Lys ${ }^{40}($ Ahx-HYNIC-99mTc/ethylenediaminediacetic acid [EDDA]) $\mathrm{NH}_{2}$ ]-exendin-4, compared with its ${ }^{111} \mathrm{In}-$ and ${ }^{68} \mathrm{Ga}-$ labeled sister compounds, showed significantly less tumor and organ uptake. The significantly lower tumor and organ uptake of [Lys ${ }^{40}$ (Ahx-HYNIC-99mTc/EDDA) $\mathrm{NH}_{2}$ ]-exendin-4 did not result in inferior tumor-to-organ ratios or reduced image quality. All radiopeptides tested showed a high tumor-to-background ratio, resulting in the visualization of small tumors (maximum diameter between 1.0 and $3.2 \mathrm{~mm}$ ) by SPECT and PET. The only exception was the kidneys, which also showed high uptake. This uptake could be reduced by $49 \%-78 \%$ using poly-glutamic acid, Gelofusine, or a combination of the 2 . The estimated effective radiation dose was $3.7 \mu \mathrm{Sv} / \mathrm{MBq}$ for [Lys ${ }^{40}$ (Ahx-HYNIC-99mTc/ EDDA) $\mathrm{NH}_{2}$ ]-exendin-4, which was 8 times less than that for $\left[\right.$ Lys $^{40}\left(\right.$ Ahx-DOTA- $\left.\left.{ }^{68} \mathrm{Ga}\right) \mathrm{NH}_{2}\right]$-exendin-4 and 43 times less than

Received Jan. 16, 2010; revision accepted Mar. 11, 2010.

For correspondence or reprints contact: Helmut R. Mäcke, University

Hospital Freiburg, Hugstetter Strasse 55, D-79106 Freiburg, Germany.

E-mail: helmut.maecke@uniklinik-freiburg.de

COPYRIGHT () 2010 by the Society of Nuclear Medicine, Inc. that for $\left[\right.$ Lys $^{40}\left(A h x-D O T A-{ }^{111} I n\right) N_{2} H_{2}$-exendin-4. Conclusion: These promising pharmacokinetic and imaging data show that $\left[\mathrm{Lys}^{40}\left(\mathrm{Ahx}-\mathrm{DOTA}-{ }^{68} \mathrm{Ga}\right) \mathrm{NH}_{2}\right]$-exendin-4 and [ $\mathrm{Lys}^{40}(\mathrm{Ahx}-$ HYNIC- $99 \mathrm{mTC}$ /EDDA) $\mathrm{NH}_{2}$ ]-exendin-4 are suitable candidates for clinical GLP-1 receptor imaging studies.

Key Words: glucagon-like peptide-1 receptor; insulinoma; exendin-4; ${ }^{88} \mathrm{Ga} ;{ }^{99 m T c}$

J Nucl Med 2010; 51:1059-1067

DOI: 10.2967/jnumed.110.074914

$\mathbf{O}$ ver the last $15 \mathrm{y}$, peptide receptor targeting of cancer cells with radiolabeled peptides has become an important method for the diagnosis and treatment of cancer patients $(1,2)$.

The high-density distribution of membrane peptide receptors in many different tumors, as shown on in vitro autoradiographic studies, represents the molecular basis of this application (1). [ ${ }^{111} \mathrm{In}$-diethylenetriaminepentaacetic acid (DTPA) ${ }^{0}$-octreotide (OctreoScan; Covidien) was the first probe for somatostatin receptor subtype 2 targeting to become an integral part of the routine diagnostic work-up of patients with gastroenteropancreatic neuroendocrine tumors (3). Especially in gut carcinoid tumors and gastrinomas, $\left[{ }^{111} \mathrm{In}-\mathrm{DTPA}^{0}\right]$-octreotide proved superior to conventional imaging methods such as sonography, CT, and MRI (4-6). In insulinomas, the sensitivity of $\left[{ }^{111} \mathrm{In}-\right.$ DTPA $^{0}$-octreotide is below $50 \%$ (7) because somatostatin receptor subtype 2 is expressed by less than $60 \%$ of insulinomas (8). The conventional imaging methods also have limited sensitivity because of the small size of insulinomas $(9,10)$. The amine precursor $6-{ }^{18} \mathrm{~F}$-fluoro-Ldopa shows controversial results, with sensitivities ranging from $17 \%$ up to $90 \%(11,12)$. Only angiography in combination with intraarterial calcium stimulation and 
venous sampling has been shown to improve the sensitivity, but this is an invasive procedure with a concomitant risk of complications (13). Thus, there is a clear need for a method that improves preoperative insulinoma imaging, especially in view of the fact that preoperative localization facilitates surgery for insulinoma, which is the only curative treatment option $(10,14)$.

A promising new approach is the targeting of glucagonlike peptide-1 (GLP-1) receptors because their high densities in insulinoma provide an attractive target for imaging using GLP-1 receptor-avid radioligands. Especially in benign insulinoma, the GLP-1 receptor density is high, with almost 100\% incidence (8). Consequently, GLP-1 receptor-avid radioligands have been developed and evaluated $(15,16)$. Preclinical animal studies have shown the ability of $\left[\mathrm{Lys}^{40}\left(\mathrm{Ahx}\right.\right.$ [6-aminohexanoic acid]-DTPA- $\left.{ }^{111} \mathrm{In}\right) \mathrm{NH}_{2}$ ]-exendin-4 to successfully localize small insulinomas in the Rip1Tag2 mouse tumor model (17). Treatment studies in the same animal tumor model have even shown the potential of GLP-1 receptor targeting as a therapeutic approach (18). Most important, the first trials in patients showed promising results in the noninvasive localization of insulinomas (19). In 6 of 6 patients, $\left[\mathrm{Lys}^{40}\left(\mathrm{Ahx}-\mathrm{DOTA}-{ }^{111} \mathrm{In}\right) \mathrm{NH}_{2}\right]$-exendin-4 SPECT/CT successfully detected pancreatic and ectopic insulinomas, which had previously not been identified with certainty using conventional methods (20). However, $\left[\mathrm{Lys}^{40}\right.$ (Ahx-DOTA- $\left.{ }^{111} \mathrm{In}\right) \mathrm{NH}_{2}$ ]-exendin-4 has several drawbacks related to the use of ${ }^{111} \mathrm{In}$, resulting in a relatively high radiation burden for the patient. A ${ }^{99 \mathrm{~m} T c-l a b e l e d ~ G L P-1}$ receptor analog may overcome these drawbacks, and a PET tracer may have advantages over conventional GLP-1 receptor imaging with ${ }^{111} \mathrm{In}$.

The aim of this study was the preclinical evaluation of $\left[\mathrm{Lys}^{40}\right.$ (Ahx-DOTA- ${ }^{68} \mathrm{Ga}$ ) $\mathrm{NH}_{2}$ ]-exendin-4 for PET/CT and [Lys ${ }^{40}$ (Ahx-hydrazinonicotinamide [HYNIC]- ${ }^{99 m}$ Tc/ethylenediaminediacetic acid [EDDA]) $\mathrm{NH}_{2}$ ]-exendin-4 for SPECT/CT. Internalization, biodistribution, imaging, and dosimetry studies were performed and compared with our gold standard, [Lys ${ }^{40}\left(\right.$ Ahx-DOTA- $\left.{ }^{111} \mathrm{In}\right) \mathrm{NH}_{2}$ ]-exendin-4. Most in vivo studies were performed in transgenic Rip1Tag2 mice, which is an animal model suitable for in vivo GLP-1 receptor targeting (17).

\section{MATERIALS AND METHODS}

Abbreviations of the common amino acids are in accordance with the recommendations of the Commission of Biochemical Nomenclature of the International Union of Pure and Applied Chemistry-International Union of Biochemistry (21).

\section{Reagents and Instrumentation}

[Lys ${ }^{40}(\mathrm{Ahx}-\mathrm{DOTA}) \mathrm{NH}_{2}$ ]-exendin-4 and [Lys $\left.{ }^{40}(\mathrm{Ahx}-\mathrm{HYNIC}) \mathrm{NH}_{2}\right]-$ exendin-4 were custom-synthesized by Anawa Trading SA and Peptide Specialty Laboratories $\mathrm{GmbH}$, respectively. Matrix-assisted laser desorption ionization-mass spectrometry measurements were done on a Voyager sSTR equipped with an Nd:YAG laser (355 nm) (Applied BioSystems). ${ }^{67} \mathrm{GaCl}_{3},{ }^{111} \mathrm{InCl}_{3}$, and the ${ }^{99} \mathrm{Mo} /{ }^{99 \mathrm{~m}} \mathrm{Tc}$ generator were obtained from Covidien. The ${ }^{68} \mathrm{Ge} /{ }^{68} \mathrm{Ga}$ generator was delivered by Eckert and Ziegler. Analytic reversedphase high-performance liquid chromatography (HPLC) was performed on a Bischof HPLC system (Metrohm AG) with HPLC pumps (model 2250) and a $\lambda-1010$ ultraviolet detector (Metrohm AG), as described elsewhere (17).

Dulbecco's modified Eagle's medium (high glucose, $\mathrm{pH}$ 7.4) supplemented with $10 \%$ fetal bovine serum, $2 \%$ L-glutamine, and $1 \%$ penicillin-streptomycin from Gibco BRL was used. C57BL/6J mice and transgenic Rip1Tag2 mice were scanned and analyzed either with an inline PET/CT system (Discovery STE; GE Healthcare) or with an MRI scanner (Magnetom Expert; Siemens) and a SPECT scanner (e.cam SPECT scanner; Siemens), which was modified with a multipinhole aperture (22). SPECT images were reconstructed using a HiSPECT reconstruction program (SciVis). SPECT and MR images were manually fused on a Hermes workstation (Hermes Medical Solutions). All dosimetric calculations were performed using the OLINDA/EXM 1.0 software (Vanderbilt University, 2003) (23).

\section{Radiolabeling of Peptides}

$\left[\mathrm{Lys}^{40}(\mathrm{Ahx}-\mathrm{DOTA}) \mathrm{NH}_{2}\right.$ ]-exendin-4 with ${ }^{111} \mathrm{InCl}_{3}$ was radiolabeled as previously described (17). The radiolabeled solution was then subjected to quality control by analytic reversed-phase HPLC.

[Lys ${ }^{40}(\mathrm{Ahx}-\mathrm{DOTA}) \mathrm{NH}_{2}$ ]-exendin-4 was radiolabeled with ${ }^{67} \mathrm{Ga}$ as described for ${ }^{111} \mathrm{InCl}_{3}$. An aliquot of $40 \mu \mathrm{L}(0.2 \mathrm{mmol} / \mathrm{L}$, $40 \mu \mathrm{g}$ ) of peptide was dissolved in $200 \mu \mathrm{L}$ of sodium acetate buffer $(0.4 \mathrm{~mol} / \mathrm{L}, \mathrm{pH} 5.0)$ before $23 \mathrm{MBq}$ of ${ }^{67} \mathrm{GaCl}_{3}$ were added.

${ }^{68} \mathrm{Ga}$ was eluted from a commercially available generator according to the method of Zhernosekov et al. (24). Afterward, the eluate was purified of ${ }^{68} \mathrm{Ge}(\mathrm{IV}), \mathrm{Zn}(\mathrm{II}), \mathrm{Ti}(\mathrm{IV})$, and $\mathrm{Fe}(\mathrm{III})$ using a 50W-X8 cation exchanger chromatographic column (BioRad) ( $<400$ mesh) and $80 \%$ acetone/0.15N hydrochloric acid. After elution from the exchanger column $(400 \mu \mathrm{L}$ of $97.6 \%$ acetone $/ 0.05 \mathrm{~N} \mathrm{HCl}$ solution), ${ }^{68} \mathrm{Ga}(\mathrm{III})$ was incubated with $50 \mu \mathrm{g}$ of $\left[\mathrm{Lys}^{40}\left(\mathrm{Ahx}\right.\right.$-DOTA) $\left.\mathrm{NH}_{2}\right]$-exendin-4 in a $0.25 \mathrm{M} \mathrm{N}$-(2-hydroxyethyl)piperazine- $N^{\prime}$-(2-ethanesulfonic acid) solution $(400 \mu \mathrm{L}$; $\mathrm{pH}$ 3.6-3.9) for $5 \mathrm{~min}$ at $95^{\circ} \mathrm{C}$ using a microwave oven (Biotage).

The radiolabeling of $\left[\mathrm{Lys}^{40}(\mathrm{Ahx}-\mathrm{HYNIC}) \mathrm{NH}_{2}\right]$-exendin-4 with ${ }^{99 \mathrm{~m}} \mathrm{Tc}$ followed a 2-vial kit formulation. One milliliter of a solution containing $15 \mathrm{mg}(84 \mu \mathrm{mol})$ of tricine, $35 \mu \mathrm{g}$ of $\left[\mathrm{Lys}^{40}(\mathrm{Ahx}-\right.$ $\mathrm{HYNIC}) \mathrm{NH}_{2}$ ]-exendin-4, and $40 \mu \mathrm{g}$ of $\mathrm{SnCl}_{2}(10 \mu \mathrm{L}$ of $22.2 \mathrm{mM}$ $\mathrm{SnCl}_{2} \cdot 2 \mathrm{H}_{2} \mathrm{O}$ in $0.1 \mathrm{M} \mathrm{HCl}$ ) was filtered into a glass vial strictly under air protection. One-half milliliter of a solution containing $5 \mathrm{mg}$ of EDDA (pH was adjusted to 7 with $1 \mathrm{M} \mathrm{NaOH}$ ) was filtered into a second glass vial. The glass vials were immediately frozen in liquid nitrogen, lyophilized, and closed afterward under a vacuum. For labeling, the EDDA vial was reconstituted with $0.5 \mathrm{~mL}$ of saline and added to the $\left[\mathrm{Lys}^{40}(\mathrm{Ahx}-\mathrm{HYNIC}) \mathrm{NH}_{2}\right]-$ exendin- 4 vial, followed by $370 \mathrm{MBq}$ of ${ }^{99} \mathrm{mcO}_{4}{ }^{-}$, and incubated for $10 \mathrm{~min}$ at $95^{\circ} \mathrm{C}$. After cooling to room temperature, the reaction mixture was analyzed by HPLC.

\section{Cell Culture, Radioligand Internalization, and Externalization Studies}

GLP-1 receptor-expressing $\beta$-tumor cells were established from $\beta$-cell tumors of Rip1Tag2 mice, as described previously (17). For internalization experiments, the cells were seeded at a density of $0.8-1$ million cells per well in 6-well plates and incubated overnight with internalization buffer. Afterward, $0.25 \mathrm{pmol}$ of the respective radiopeptide was added to the medium 
(final concentration, $0.17 \mathrm{nmol} / \mathrm{L}$ ) and incubated at $37^{\circ} \mathrm{C}$. To determine nonspecific membrane binding and internalization, a large excess of unlabeled peptide was used in selected wells. The internalization was stopped at appropriate time points (30 min and 1,2 , and $4 \mathrm{~h}$ ) by removing the medium, and the cells were treated as described previously (17).

For externalization studies, $\beta$-tumor cells $(0.8-1$ million) were incubated with $0.25 \mathrm{pmol}$ of radiopeptide $(0.17 \mathrm{nmol} / \mathrm{L})$ for $120 \mathrm{~min}$. Then the medium was removed, and the cells were treated as described previously (17). All in vitro experiments were performed twice (triplicates in each experiment).

\section{Animal Model}

Animals were maintained and treated in compliance with the guidelines of the Swiss regulations (approval 789). Male and female Rip1Tag2 transgenic mice and female wild-type mice (C57BL/6J mice) were used for biodistribution studies, pinhole SPECT/MRI, and PET/CT. Transgenic Rip1Tag2 mice developed $\beta$-cell tumors in the pancreas in a multistage tumorigenesis pathway. These tumors were characterized by a high expression of GLP-1 receptors (17). Phenotypic and genotypic analyses of Rip1Tag2 mice have been described previously (25). At intervention, all mice were between 11 and 13 wk old.

\section{Biodistribution in Rip1Tag2 Mice}

Ten picomoles $(70-110 \mathrm{kBq})$ of the respective radiopeptide diluted in $100 \mu \mathrm{L}$ of a $1 \%$ human albumin solution were injected into the tail vein of Rip1Tag2 mice. Rip1Tag2 mice were sacrificed at the following time points after injection $(n=3-6$ per time point): For $\left[\mathrm{Lys}^{40}\left(\mathrm{Ahx}-\mathrm{DOTA}-{ }^{11} \mathrm{In}\right) \mathrm{NH}_{2}\right]$-exendin-4, mice were sacrificed at $1,4,12,36,84$, and $168 \mathrm{~h}$ ); for $\left[\right.$ Lys $^{40}\left(\right.$ Ahx-DOTA- $\left.{ }^{68} \mathrm{Ga}\right) \mathrm{NH}_{2}$ ]-exendin-4, at $0.5,1,2$, and $4 \mathrm{~h}$; and for $\left[\mathrm{Lys}^{40}\left(\mathrm{Ahx}-\mathrm{HYNIC}-{ }^{99 \mathrm{~m}} \mathrm{Tc} / \mathrm{EDDA}\right) \mathrm{NH}_{2}\right]$-exendin-4, at 0.5 , 2, 4, and $18 \mathrm{~h}$. Organs, blood, and tumors were collected, and the radioactivity was measured in a $\gamma$-counter. The radioactivity uptake in organs and tumors was calculated as percentage of injected activity per gram of tissue $(\% \mathrm{IA} / \mathrm{g})$ and percentage of injected activity per organ (\%IA/organ).

To determine the nonspecific uptake of the respective radiopeptide, Rip1Tag2 mice were coinjected with 10 pmol of the radiolabeled peptide and $5 \mathrm{nmol}$ of the respective nonlabeled peptide and sacrificed $4 \mathrm{~h}$ later.

\section{Radiation Dose Calculation}

Mice biodistribution data were used to generate the residence time for each radiopeptide. Because of the absence of specific activity accumulation in bones and red marrow (18), a linear relationship between the blood residence time and red marrow residence time was assumed to estimate the red marrow radiation dose (26). The proportionality factor was the ratio between the red marrow mass and the blood mass in humans.

OLINDA/EXM was used to integrate the fitted time-activity curves. Organ and effective doses were estimated with OLINDA/ EXM using the whole-body adult female model and the weighting factors recommended by the International Commission on Radiological Protection (27). For all calculations, the assumption was made that the Rip1Tag2 mouse biodistribution, determined as the $\%$ IA/organ, was the same as the human biodistribution.

\section{GLP-1 Receptor Imaging with Multipinhole SPECT/MRI}

Two Rip1Tag2 mice were injected with $37 \mathrm{MBq}$ of $\left[\mathrm{Lys}^{40}(\mathrm{Ahx}-\right.$ HYNIC- ${ }^{99} \mathrm{~m}$ Tc/EDDA) $\mathrm{NH}_{2}$ ]-exendin- 4 into the tail vein. Four hours after injection, multipinhole SPECT images of both Rip1Tag2 mice (under isoflurane anesthesia and lying prone) were obtained (22). Images were acquired from 60 angles, with a minimum of 30 kilo counts per angle, resulting in a scan time of $60 \mathrm{~min}$. Shortly thereafter, Rip1Tag2 mice were scanned in an MRI scanner in the same position. To enhance the signal-to-noise ratio, a specially designed and modified small-animal saddle coil was used. Coronal high-resolution slices were obtained using a 3-dimensional (3D) double-echo-in-steady-state sequence. Transverse slices were reconstructed from the $3 \mathrm{D}$ dataset to obtain slices for image fusion. Reconstructed transverse MR and SPECT images were manually fused using the anatomic information obtained from both imaging modalities. After imaging, necropsy was performed in both animals, and the size of tumors was measured.

\section{GLP-1 Receptor Imaging with PET/CT}

One Rip1Tag2 mouse was injected with 10 pmol (130 kBq) of [Lys ${ }^{40}\left(\right.$ Ahx-DOTA- $\left.{ }^{68} \mathrm{Ga}\right) \mathrm{NH}_{2}$ ]-exendin-4 as described above. Sixty minutes after injection, the mouse was sacrificed and bilateral nephrectomy was performed. PET images (3D mode) of the mouse lying prone were obtained for $1 \mathrm{~h}$ with a PET/CT hybrid scanner. The image matrix was $256 \times 256$, and images were reconstructed as 1-mm-thick sections using an iterative algorithm. The CT data from the PET/CT examination were reconstructed in the transverse plane as 1-mm-thick sections. The following parameters were used for imaging: $130 \mathrm{kV}$, $80 \mathrm{mAs}, 1.5 \mathrm{~s}$ per rotation, and $1 \mathrm{~mm} / \mathrm{s}$ table speed.

\section{Renal Uptake Reduction Studies}

For renal uptake reduction studies, $80 \mathrm{mg}$ (3-15 kD) of L-polyglutamic acid (PGA; Sigma-Aldrich) per milliliter or $40 \mathrm{mg}$ of Gelofusine (Braun) per milliliter were dissolved in saline as described previously (28). Rip1Tag2 mice were injected intravenously with $100 \mu \mathrm{L}$ of one solution or $200 \mu \mathrm{L}$ of both solutions just before intravenous administration of $10 \mathrm{pmol}$ of

\begin{tabular}{|c|c|c|c|c|}
\hline Compound & $0.5 \mathrm{~h}$ & $1 \mathrm{~h}$ & $2 \mathrm{~h}$ & $4 \mathrm{~h}$ \\
\hline$\left[\right.$ Lys $^{40}\left(\mathrm{Ahx}\right.$-DOTA- ${ }^{111}$ In) $\left.\mathrm{NH}_{2}\right]$-exendin-4 & $1.03 \pm 0.14$ & $2.03 \pm 0.18$ & $4.97 \pm 0.4$ & $9.75 \pm 0.65$ \\
\hline$\left[\right.$ Lys $\left.^{40}\left(\mathrm{Ahx}-\mathrm{DOTA}-{ }^{67} \mathrm{Ga}\right) \mathrm{NH}_{2}\right]$-exendin-4 & $1.22 \pm 0.08$ & $2.48 \pm 0.29$ & $5.10 \pm 0.26$ & $10.35 \pm 0.43$ \\
\hline$\left[\right.$ Lys $\left.^{40}\left(\mathrm{Ahx}-\mathrm{HYNIC-}{ }^{-99 m T c / E D D A}\right) \mathrm{NH}_{2}\right]$-exendin-4 & $0.73 \pm 0.29$ & $1.50 \pm 0.49$ & $3.37 \pm 1.27$ & $6.50 \pm 1.94$ \\
\hline 1-way ANOVA & $P=0.002$ & $P=0.001$ & $P=0.003$ & $P=0.0001$ \\
\hline
\end{tabular}




\begin{tabular}{|c|c|c|c|c|}
\hline Organ & $0.5 \mathrm{~h}$ & $1 \mathrm{~h}$ & $2 \mathrm{~h}$ & $4 \mathrm{~h}$ \\
\hline Lungs* & $40.8 \pm 3.5$ & $42.5 \pm 5.1$ & $31.4 \pm 2.9$ & $42.5 \pm 5.1$ \\
\hline Pancreas* & $17.0 \pm 2.4$ & $13.5 \pm 4.4$ & $16.8 \pm 6.3$ & $13.5 \pm 1.0$ \\
\hline Stomach* & $4.05 \pm 0.33$ & $4.08 \pm 0.59$ & $2.56 \pm 0.35$ & $2.14 \pm 0.77$ \\
\hline Tumor* & $185 \pm 33$ & $209 \pm 44$ & $207 \pm 60$ & $205 \pm 59$ \\
\hline Kidneys & $255 \pm 14$ & $230 \pm 33$ & $252 \pm 24$ & $202 \pm 34$ \\
\hline Liver & $0.88 \pm 0.04$ & $0.61 \pm 0.11$ & $0.63 \pm 0.12$ & $0.61 \pm 0.11$ \\
\hline Spleen & $2.14 \pm 0.12$ & $1.91 \pm 0.50$ & $2.10 \pm 0.73$ & $2.28 \pm 0.59$ \\
\hline Muscle & $1.30 \pm 0.10$ & $1.13 \pm 0.51$ & $0.97 \pm 0.09$ & $1.00 \pm 1.03$ \\
\hline Bone & $1.03 \pm 0.33$ & $1.01 \pm 0.91$ & $1.07 \pm 0.13$ & $0.89 \pm 0.52$ \\
\hline Blood & $2.08 \pm 0.49$ & $1.35 \pm 0.17$ & $0.49 \pm 0.03$ & $0.29 \pm 0.10$ \\
\hline Tumor/blood & 88.9 & 155 & 423 & 706 \\
\hline Tumor/muscle & 142 & 185 & 214 & 205 \\
\hline Tumor/pancreas & 10.9 & 15.5 & 12.4 & 15.2 \\
\hline Tumor/lungs & 4.52 & 4.91 & 6.60 & 4.82 \\
\hline Tumor/kidneys & 0.72 & 0.91 & 0.82 & 1.01 \\
\hline
\end{tabular}

[Lys ${ }^{40}\left(\right.$ Ahx-DOTA- $\left.{ }^{68} \mathrm{Ga}\right) \mathrm{NH}_{2}$ ]-exendin-4. One hour later, Rip1Tag2 mice ( $n=3$ per cohort) were sacrificed. One control animal and 1 PGA plus Gelofusine-treated animal underwent PET/CT just before tumor and organ collection. Finally, the radioactivity uptake in organs and tumors was calculated as $\% \mathrm{IA} / \mathrm{g}$ and \%IA/organ.

\section{Statistical Analysis}

The calculation of means and SDs for internalization and biodistribution was performed in Excel (Microsoft). Correlation between the rate of internalization and tumor or lung uptake was analyzed in Microsoft Excel using linear regression analysis. Graphing and curve fitting were performed using Microcal Origin. One-way ANOVA for groups, including Tukey's posttest for pairwise comparison, was performed on Paleontological Statistics software. $P$ values less than 0.05 were considered significant.

\section{RESULTS}

Synthesis and Radiolabeling

DOTA and HYNIC were coupled via the Lys side chain of the C-terminally extended exendin- 4 using Ahx as a spacer. The composition and structural identity of $\left[\mathrm{Lys}^{40}(\mathrm{Ahx}-\right.$ DOTA) $\mathrm{NH}_{2}$ ]-exendin-4 and [Lys ${ }^{40}(\mathrm{Ahx}-\mathrm{HYNIC}) \mathrm{NH}_{2}$ ]exendin-4 were verified by analytic HPLC and matrix-assisted laser desorption ionization-mass spectrometry ([Lys ${ }^{40}(\mathrm{AhX}-$ DOTA) $\left.\mathrm{NH}_{2}\right]$-exendin-4: 4,815.21 $\left[\mathrm{M}^{+} \mathrm{H}^{+}\right]$and $\left[\mathrm{Lys}^{40}\right.$ (Ahx-HYNIC) $\left.\mathrm{NH}_{2}\right]$-exendin-4: 4,563.78 $\left[\mathrm{M}^{+} \mathrm{H}^{+}\right]$). The labeling yield of $\left[\mathrm{Lys}^{40}\left(\mathrm{Ahx}-\mathrm{DOTA}-{ }^{111} \mathrm{In}\right) \mathrm{NH}_{2}\right]$-exendin-4 and $\left[\mathrm{Lys}^{40}\left(\mathrm{Ahx}-\mathrm{HYNIC}-{ }^{99 \mathrm{~m}} \mathrm{Tc} / \mathrm{EDDA}\right) \mathrm{NH}_{2}\right.$ ]-exendin-4 was $98 \%$ and $95 \%$ at a specific activity of $19 \mathrm{GBq} / \mu \mathrm{mol}$ and $48 \mathrm{GBq} / \mu \mathrm{mol}$, respectively. [Lys ${ }^{40}\left(\mathrm{Ahx}-\mathrm{DOTA}-{ }^{68} \mathrm{Ga}\right) \mathrm{NH}_{2}$ ]-

\begin{tabular}{|c|c|c|c|c|}
\hline Organ & $0.5 \mathrm{~h}$ & $2 \mathrm{~h}$ & $4 \mathrm{~h}$ & $18 \mathrm{~h}$ \\
\hline Lungs* & $14.6 \pm 4.3$ & $18.5 \pm 5.9$ & $15.9 \pm 5.6$ & $8.7 \pm 1.9$ \\
\hline Pancreas* & $7.1 \pm 2.0$ & $9.6 \pm 1.5$ & $7.4 \pm 2.2$ & $6.0 \pm 1.4$ \\
\hline Stomach* & $1.18 \pm 0.32$ & $1.36 \pm 0.32$ & $1.20 \pm 0.30$ & $1.05 \pm 0.27$ \\
\hline Tumor* & $67 \pm 13$ & $98 \pm 19$ & $93 \pm 20$ & $50 \pm 9$ \\
\hline Kidneys & $63 \pm 10$ & $57 \pm 14$ & $60 \pm 12$ & $42 \pm 12$ \\
\hline Liver & $0.83 \pm 0.20$ & $0.71 \pm 0.28$ & $0.72 \pm 0.20$ & $0.74 \pm 0.19$ \\
\hline Spleen & $0.59 \pm 0.10$ & $0.47 \pm 0.17$ & $0.52 \pm 0.10$ & $0.58 \pm 0.10$ \\
\hline Muscle & $0.16 \pm 0.08$ & $0.13 \pm 0.10$ & $0.17 \pm 0.08$ & $0.09 \pm 0.05$ \\
\hline Bone & $0.19 \pm 0.03$ & $0.16 \pm 0.03$ & $0.18 \pm 0.03$ & $0.21 \pm 0.02$ \\
\hline Blood & $2.34 \pm 0.47$ & $0.55 \pm 0.11$ & $0.35 \pm 0.13$ & $0.19 \pm 0.12$ \\
\hline Tumor/blood & 29 & 177 & 266 & 262 \\
\hline Tumor/muscle & 419 & 754 & 547 & 556 \\
\hline Tumor/pancreas & 9.5 & 10.2 & 12.6 & 8.4 \\
\hline Tumor/lungs & 4.59 & 5.29 & 5.86 & 10.6 \\
\hline Tumor/kidneys & 1.06 & 1.72 & 1.55 & 1.18 \\
\hline
\end{tabular}


TABLE 4. Biodistribution Data and Tissue Radioactivity Ratios at 4 Hours After Injection of Respective Radiopeptide

\begin{tabular}{|c|c|c|c|c|c|}
\hline Organs & $\begin{array}{c}\text { Study } \\
\text { parameter* }\end{array}$ & $\begin{array}{l}\text { [Lys }{ }^{40}(\mathrm{Ahx}- \\
\text { DOTA- } \\
\left.{ }^{111} \text { In)NH } \mathrm{NH}_{2}\right]- \\
\text { exendin-4 }\end{array}$ & $\begin{array}{l}{\left[\mathrm{Lys}^{40}(\mathrm{Ahx}-\right.} \\
\text { DOTA- } \\
\left.\left.{ }^{68} \mathrm{Ga}\right) \mathrm{NH}_{2}\right]- \\
\text { exendin-4 }\end{array}$ & $\begin{array}{c}\text { Lys }^{40}(\mathrm{Ahx}- \\
\text { HYNIC- } \\
\left.\text { 99mTc/EDDA)NH }{ }_{2}\right]- \\
\text { exendin-4 }\end{array}$ & $\begin{array}{l}P \text { (1-way } \\
\text { ANOVA) }\end{array}$ \\
\hline \multirow[t]{2}{*}{ Lungs $^{\dagger}$} & Nonblocked & $39.7 \pm 6.8$ & $42.5 \pm 5.1$ & $15.9 \pm 5.6$ & $<0.0001$ \\
\hline & Blocked & $0.57 \pm 0.01$ & $0.90 \pm 0.25$ & $0.65 \pm 0.17$ & \\
\hline \multirow[t]{2}{*}{ Pancreas $^{\dagger}$} & Nonblocked & $17.8 \pm 3.9$ & $13.5 \pm 1.0$ & $7.4 \pm 2.2$ & $<0.0001$ \\
\hline & Blocked & $0.90 \pm 0.26$ & $0.79 \pm 0.27$ & $0.34 \pm 0.16$ & \\
\hline \multirow[t]{2}{*}{ Stomach $^{\dagger}$} & Nonblocked & $3.31 \pm 0.86$ & $2.14 \pm 0.77$ & $1.20 \pm 0.30$ & $<0.0001$ \\
\hline & Blocked & $0.60 \pm 0.02$ & $1.22 \pm 0.40$ & $0.35 \pm 0.07$ & \\
\hline \multirow[t]{2}{*}{ Tumor ${ }^{\dagger}$} & Nonblocked & $213 \pm 75$ & $205 \pm 59$ & $93.1 \pm 19.9$ & $<0.0001$ \\
\hline & Blocked & $9.35 \pm 4.18$ & $5.62 \pm 3.85$ & $5.45 \pm 0.43$ & \\
\hline \multirow[t]{2}{*}{ Kidney } & Nonblocked & $243 \pm 17$ & $202 \pm 34$ & $60 \pm 12$ & $<0.0001$ \\
\hline & Blocked & $257 \pm 30$ & $193 \pm 81$ & $48 \pm 7$ & \\
\hline \multirow[t]{2}{*}{ Liver } & Nonblocked & $1.03 \pm 0.12$ & $0.61 \pm 0.11$ & $0.72 \pm 0.2$ & $<0.0001$ \\
\hline & Blocked & $0.85 \pm 0.18$ & $0.51 \pm 0.28$ & $0.54 \pm 0.21$ & \\
\hline \multirow[t]{2}{*}{ Spleen } & Nonblocked & $2.17 \pm 0.54$ & $2.28 \pm 0.59$ & $0.52 \pm 0.1$ & $<0.0001$ \\
\hline & Blocked & $1.77 \pm 0.58$ & $1.37 \pm 0.47$ & $0.37 \pm 0.14$ & \\
\hline \multirow[t]{2}{*}{ Muscle } & Nonblocked & $1.23 \pm 0.76$ & $1.00 \pm 1.03$ & $0.17 \pm 0.08$ & 0.008 \\
\hline & Blocked & $0.78 \pm 0.32$ & $0.82 \pm 0.10$ & $0.08 \pm 0.03$ & \\
\hline \multirow[t]{2}{*}{ Bone } & Nonblocked & $0.36 \pm 0.20$ & $0.89 \pm 0.52$ & $0.18 \pm 0.03$ & 0.01 \\
\hline & Blocked & $0.13 \pm 0.03$ & $0.46 \pm 0.26$ & $0.16 \pm 0.09$ & \\
\hline \multirow[t]{2}{*}{ Blood } & Nonblocked & $0.26 \pm 0.08$ & $0.29 \pm 0.10$ & $0.35 \pm 0.13$ & 0.69 \\
\hline & Blocked & $0.24 \pm 0.03$ & $0.39 \pm 0.25$ & $0.50 \pm 0.29$ & \\
\hline \multicolumn{2}{|l|}{ Tumor/blood } & 820 & 706 & 266 & \\
\hline \multicolumn{2}{|l|}{ Tumor/muscle } & 173 & 205 & 547 & \\
\hline \multicolumn{2}{|l|}{ Tumor/pancreas } & 12.0 & 15.2 & 12.6 & \\
\hline \multicolumn{2}{|l|}{ Tumor/lungs } & 5.37 & 4.82 & 5.86 & \\
\hline \multicolumn{2}{|l|}{ Tumor/kidneys } & 0.88 & 1.01 & 1.55 & \\
\hline \multicolumn{6}{|c|}{$\begin{array}{l}\text { *Blocked studies were blocked with } 5 \mathrm{nmol} \text { of respective peptide. } \\
{ }^{\dagger} \mathrm{GLP}-1 \text { receptor-positive organs. }\end{array}$} \\
\hline
\end{tabular}

exendin- 4 was radiolabeled using microwave heating with a labeling yield of greater than $98 \%$ at a specific activity of $13 \mathrm{GBq} / \mu \mathrm{mol}$.

\section{In Vitro Internalization and Externalization Studies}

Table 1 shows the results of specific internalization of GLP-1 receptor agonists into $\beta$-tumor cells. Between $80 \%$ and $99 \%$ of totally internalized radioligands were specifically internalized. The rate of internalization was not significantly different between the ${ }^{111} \mathrm{In}$ - and the ${ }^{67} \mathrm{Ga}-$ labeled exendin-4. A significant difference was found between ${ }^{99 \mathrm{~m}} \mathrm{Tc}$ - and ${ }^{111} \mathrm{In}$ - and between ${ }^{99 \mathrm{~m}} \mathrm{Tc}$ - and ${ }^{67} \mathrm{Ga}-$ labeled exendin- 4 .

The kinetics of externalization were studied with $\beta$-tumor cells exposed to the radiopeptide for $2 \mathrm{~h}$ at $37^{\circ} \mathrm{C}$. Within $4 \mathrm{~h}$, only $18.7 \%-23 \%$ of the radioligands were released from the $\beta$-tumor cells and the externalization leveled off (not shown). There was no significant difference in the rate of externalization among the 3 radiopeptides.

\section{Animal Biodistribution Studies}

We have shown previously that the tumor uptake of $\left[\mathrm{Lys}^{40}\left(\mathrm{Ahx}-\mathrm{DTPA}{ }^{111} \mathrm{In}\right) \mathrm{NH}_{2}\right.$ ]-exendin-4 is peptide amountdependent, with the highest uptake at a peptide mass of
$10 \mathrm{pmol}(18)$. As a result, $10 \mathrm{pmol}$ of radiopeptide was used in all biodistribution experiments. Biodistribution data and tumor-to-tissue ratios of $\left[\mathrm{Lys}^{40}\left(\mathrm{Ahx}-\mathrm{DOTA}-{ }^{68} \mathrm{Ga}\right) \mathrm{NH}_{2}\right]$-ex-

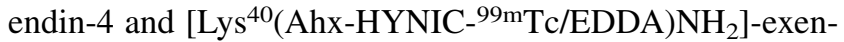
din-4 are summarized in Tables 2 and 3, respectively. Both radiopeptides showed a fast blood clearance and high tumorto-normal organ ratios already at early time points (Tables 2 and 3). One-way ANOVA showed significant differences among exendin-4 analogs (Table 4). $\left[\mathrm{Lys}^{40}(\mathrm{Ahx}-\mathrm{HY}-\right.$ NIC- ${ }^{-9} \mathrm{~m}$ Tc/EDDA)NH ${ }_{2}$ ]-exendin-4 showed the lowest and [Lys ${ }^{40}$ (Ahx-DOTA- ${ }^{111} \mathrm{In}$ ) $\mathrm{NH}_{2}$ ]-exendin-4 the highest tumor and organ uptake. Tukey's posttest for individual comparison showed no difference in tumor uptake between [Lys ${ }^{40}$ (Ahx-DOTA- $\left.{ }^{111} \mathrm{In}\right) \mathrm{NH}_{2}$ ]-exendin-4 and [ $\mathrm{Lys}^{40}$ (Ahx-DOTA$\left.{ }^{68} \mathrm{Ga}\right) \mathrm{NH}_{2}$ ]-exendin-4. The accumulated activity in GLP-1 receptor-expressing organs such as lung and pancreas was high, at $42.5 \pm 5.1 \% \mathrm{IA} / \mathrm{g}$ and $13.5 \pm 1.0 \% \mathrm{IA} / \mathrm{g} 4 \mathrm{~h}$ after injection of $\left[\mathrm{Lys}^{40}\left(\mathrm{Ahx}-\mathrm{DOTA}-{ }^{68} \mathrm{Ga}\right) \mathrm{NH}_{2}\right]$-exendin-4. The highest uptake was found in the tumor and kidneys at $4 \mathrm{~h}$ after injection of the ${ }^{111} \mathrm{In}$ - and ${ }^{68} \mathrm{Ga}$-labeled DOTA conjugate. Blocking with a 500-times excess of the respective cold ligand reduced the tumor uptake of all tested radiopeptides by more than $94 \%$, whereas the kidney uptake was not affected. 
TABLE 5. Radiation Dose Estimation Extrapolated to Humans After Injection of ${ }^{111} \mathrm{In}$-, ${ }^{68} \mathrm{Ga}$, and ${ }^{99 \mathrm{~m} T c-L a b e l e d}$ Exendin-4

\begin{tabular}{|c|c|c|c|}
\hline Organ/tissue & {$\left[\right.$ Lys $\left.^{40}\left(\mathrm{Ahx}-\mathrm{DOTA}-{ }^{111} \mathrm{In}\right) \mathrm{NH}_{2}\right]$-exendin-4 } & $\begin{array}{l}{\left[\text { Lys }^{40}(\mathrm{Ahx}-\right.} \\
\left.\text { DOTA-68 } \mathrm{Ga}) \mathrm{NH}_{2}\right]- \\
\text { exendin-4 }\end{array}$ & $\begin{array}{c}{\left[\text { Lys }^{40}(\text { Ahx- }\right.} \\
\left.\text { HYNIC-99mTc/EDDA)NH }{ }_{2}\right]- \\
\text { exendin-4 }\end{array}$ \\
\hline Adrenals & 0.43 & 0.050 & 0.0079 \\
\hline Brain & 0.064 & 0.014 & 0.0014 \\
\hline Breasts & 0.064 & 0.015 & 0.0015 \\
\hline Gallbladder wall & 0.26 & 0.029 & 0.0057 \\
\hline Gastrointestinal & 0.14 & 0.020 & 0.0032 \\
\hline \multicolumn{4}{|l|}{ Lower large intestine wall } \\
\hline Small intestine & 0.32 & 0.068 & 0.0097 \\
\hline Stomach wall & 0.20 & 0.029 & 0.0046 \\
\hline Upper large intestine wall & 0.23 & 0.026 & 0.0055 \\
\hline Heart wall & 0.10 & 0.01 & 0.0025 \\
\hline Kidneys & 4.48 & 1.85 & 0.083 \\
\hline Liver & 0.20 & 0.020 & 0.0046 \\
\hline Lungs & 0.13 & 0.044 & 0.0046 \\
\hline Muscle & 0.12 & 0.019 & 0.0024 \\
\hline Ovaries & 0.16 & 0.021 & 0.0039 \\
\hline Pancreas & 0.70 & 0.20 & 0.020 \\
\hline Red marrow & 0.14 & 0.020 & 0.0030 \\
\hline Osteogenic cells & 0.23 & 0.028 & 0.0060 \\
\hline Skin & 0.064 & 0.015 & 0.0013 \\
\hline Spleen & 0.37 & 0.035 & 0.068 \\
\hline Thymus & 0.086 & 0.017 & 0.0020 \\
\hline Thyroid & 0.069 & 0.015 & 0.0015 \\
\hline Urinary bladder wall & 0.11 & 0.017 & 0.0026 \\
\hline Uterus & 0.15 & 0.021 & 0.0036 \\
\hline Total body & 0.14 & 0.029 & 0.0031 \\
\hline Effective dose (mSv/MBq) & 0.155 & 0.0317 & 0.00372 \\
\hline
\end{tabular}

Results are expressed as mean absorbed dose (mGy/MBq).

An important value for the diagnostic use of GLP-1 receptor tracers is the tumor-to-pancreas ratio, which was between 12 and 15.2 for all radiopeptides tested.

\section{Dosimetry}

Table 5 shows the radiation dose estimation extrapolated to humans after injection of $\left[\mathrm{Lys}^{40}\left(\mathrm{Ahx}-\mathrm{DOTA}-{ }^{111} \mathrm{In}\right) \mathrm{NH}_{2}\right]-$ exendin-4, [Lys $\left.{ }^{40}\left(\mathrm{Ahx}-\mathrm{DOTA}-{ }^{68} \mathrm{Ga}\right) \mathrm{NH}_{2}\right]$-exendin-4, and [Lys ${ }^{40}$ (Ahx-HYNIC- ${ }^{99 m}$ Tc/EDDA)NH ${ }_{2}$ ]-exendin-4. Biodistribution data expressed as \%IA/organ (Supplemental Tables 1-3; supplemental materials are available online only at http://jnm.snmjournals.org) were used to generate the residence time for each radiopeptide. The estimated effective radiation dose is $0.16 \mathrm{mSv} / \mathrm{MBq}$ for $\left[\mathrm{Lys}^{40}(\mathrm{Ahx}-\right.$ DOTA- $\left.{ }^{111} \mathrm{In}\right) \mathrm{NH}_{2}$ ]-exendin-4, $0.032 \mathrm{mSv} / \mathrm{MBq}$ for $\left[\mathrm{Lys}^{40}\right.$ (Ahx-DOTA- ${ }^{68} \mathrm{Ga}^{2} \mathrm{NH}_{2}$ ]-exendin-4, and only $0.0037 \mathrm{mSv} /$ $\mathrm{MBq}$ for $\left[\mathrm{Lys}^{40}\left(\mathrm{Ahx}-\mathrm{HYNIC}-{ }^{99 \mathrm{~m}} \mathrm{Tc} / \mathrm{EDDA}\right) \mathrm{NH}_{2}\right]$-exendin4. The highest radiation dose was calculated for the kidneys.

\section{In Vivo GLP-1 Receptor Imaging}

Figure 1 shows the iteratively reconstructed multipinhole SPECT/MR images of 1 Rip1Tag2 mouse at $4 \mathrm{~h}$ after injection of $37 \mathrm{MBq}$ of $\left[\mathrm{Lys}^{40}\right.$ (Ahx-HYNIC- ${ }^{99 \mathrm{~m}} \mathrm{Tc} / \mathrm{ED}-$ DA) $\mathrm{NH}_{2}$ ]-exendin-4. In contrast to high-resolution MRI, pinhole $\left[\mathrm{Lys}^{40}\left(\mathrm{Ahx}-\mathrm{HYNIC}-{ }^{-99 \mathrm{~m}} \mathrm{Tc} / \mathrm{EDDA}\right) \mathrm{NH}_{2}\right]$-exendin-4
SPECT visualized 4 small insulinomas with a diameter between 1.0 and $3.2 \mathrm{~mm}$. Other GLP-1 receptor-positive organs, such as the lung and pancreas, were hardly visible.
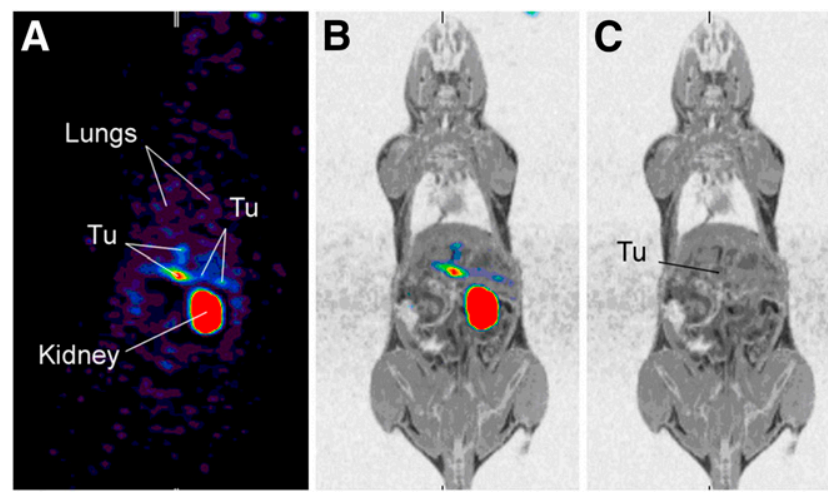

FIGURE 1. GLP-1 receptor SPECT/MRI of tumor-bearing Rip1Tag2 mouse at $4 \mathrm{~h}$ after injection of $37 \mathrm{MBq}$ of [Lys ${ }^{40}\left(\mathrm{Ahx}-\mathrm{HYNIC-}{ }^{99 m T c / E D D A}\right) \mathrm{NH}_{2}$ ]-exendin-4. Only multipinhole SPECT images $(A)$ and corresponding multipinhole SPECT/MR fused images (B) show 4 tumor lesions (Tu) in pancreas with diameter between 1 and $3.2 \mathrm{~mm}$. Corresponding MR images (C) show only largest tumor. There is intense tracer accumulation in kidneys but only weak uptake of $\left[\mathrm{Lys}^{40}\left(\mathrm{Ahx}-\mathrm{HYNIC}-{ }^{99 m T c / E D D A}\right) \mathrm{NH}_{2}\right.$ ]-exendin-4 in both lungs $(A)$. 

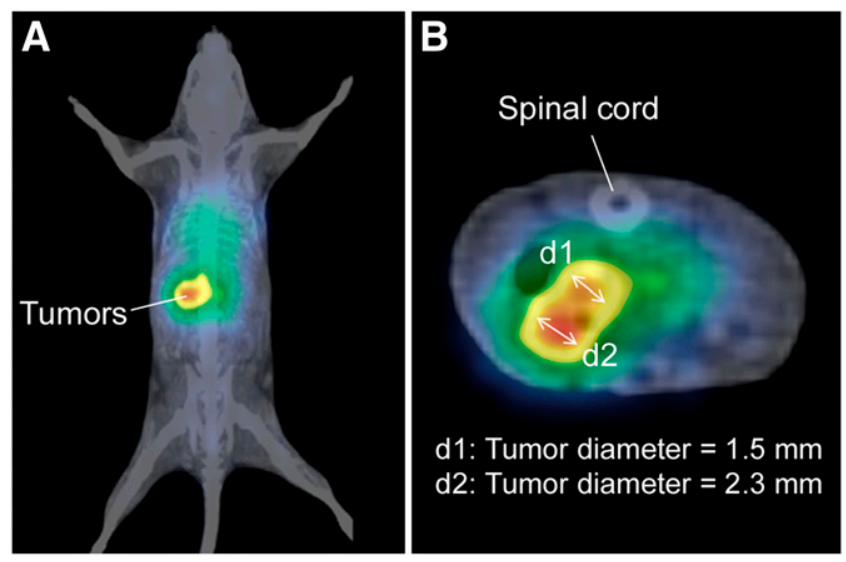

FIGURE 2. [Lys $\left.{ }^{40}\left(\mathrm{Ahx}-\mathrm{DOTA}-{ }^{68} \mathrm{Ga}\right) \mathrm{NH}_{2}\right]$-exendin-4 PET/ CT of 1 Rip1Tag2 mouse after bilateral nephrectomy. Coronal (A) and transverse (B) PET/CT images show intense [Lys ${ }^{40}\left(A h x-D O T A-{ }^{68} \mathrm{Ga}\right) \mathrm{NH}_{2}$ ]-exendin-4 uptake in 2 tumor lesions with maximum diameter of $1.5 \mathrm{~mm}$ (d1) and $2.3 \mathrm{~mm}$ (d2), respectively. The coregistered CT scan was unremarkable at same location. There is no relevant uptake of $\left[\right.$ Lys $^{40}\left(\right.$ Ahx-DOTA- $\left.{ }^{68} \mathrm{Ga}\right) \mathrm{NH}_{2}$ ]-exendin-4 elsewhere.

Figure 2 shows PET/CT images of 1 Rip1Tag2 mouse at $1 \mathrm{~h}$ after injection of $130 \mathrm{kBq}$ of $\left[\mathrm{Lys}^{40}\right.$ (Ahx-DOTA$\left.{ }^{68} \mathrm{Ga}\right) \mathrm{NH}_{2}$ ]-exendin-4. Before imaging, bilateral nephrec- tomy was performed because tumor delineation from the kidneys was not possible before nephrectomy. After nephrectomy, PET/CT images demonstrated impressive focal uptake in 2 tumors in the pancreatic body after injection of only $130 \mathrm{kBq}$ of $\left[\mathrm{Lys}^{40}\left(\mathrm{Ahx}-\mathrm{DOTA}-{ }^{68} \mathrm{Ga}\right) \mathrm{NH}_{2}\right]$-exendin- 4 (Figs. 2C and 2D). The maximal diameter of these tumors was only 2.3 and $1.5 \mathrm{~mm}$.

\section{Renal Uptake Reduction Studies}

Figures $3 \mathrm{~A}$ and $3 \mathrm{~B}$ show kidney and tumor uptake of $\left[\mathrm{Lys}^{40}\left(\mathrm{Ahx}-\mathrm{DOTA}-{ }^{68} \mathrm{Ga}\right) \mathrm{NH}_{2}\right.$ ]-exendin-4 after pretreatment with PGA or Gelofusine. The uptake in tissues other than kidneys did not differ significantly between the control group and the kidney protection group. In comparison with the control group, PGA and Gelofusine showed a kidney uptake reduction of $49 \%$ and $60 \%$, respectively $(P<0.01)$. The combination of PGA and Gelofusine was even more effective than PGA alone, with a kidney uptake reduction of $78 \%(P=0.0002)$. The tumor-to-kidney ratio was 4.9 after PGA plus Gelofusine treatment and 2.4 after Gelofusine treatment. However, no significant difference in kidney protection was found between Gelofusine alone and the combination of PGA and Gelofusine $(P=0.055)$. Figures $3 \mathrm{C}$ and 3D show $\left[\mathrm{Lys}^{40}\left(\mathrm{Ahx}-\mathrm{DOTA}-{ }^{68} \mathrm{Ga}\right) \mathrm{NH}_{2}\right]$-exendin-4 PET/CT scans of 1 animal with kidney protection and 1 animal without kidney protection.
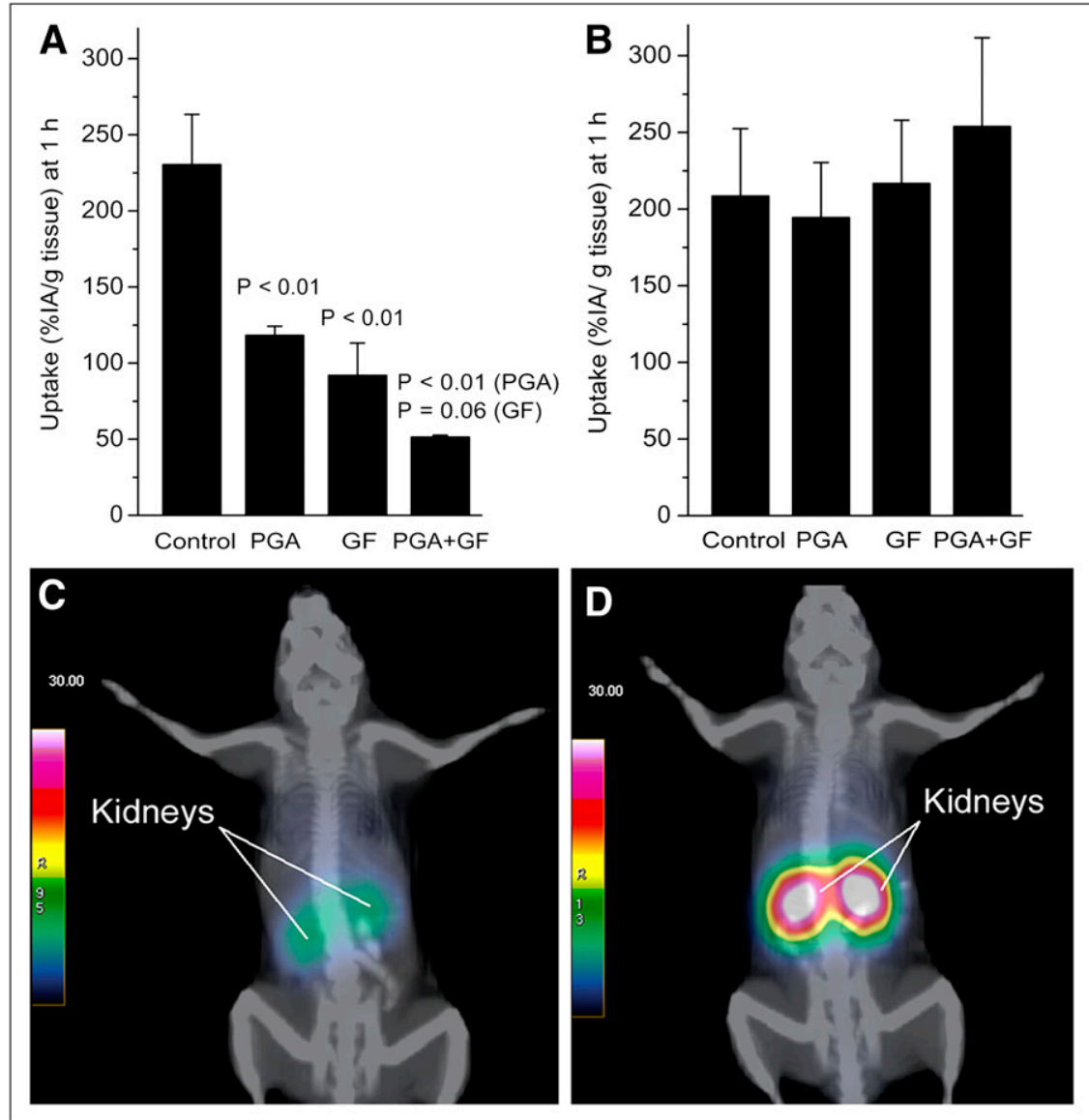

FIGURE 3. Biodistribution and PET/ CT of Rip1Tag2 mice $1 \mathrm{~h}$ after injection of $\left[\right.$ Lys ${ }^{40}\left(\right.$ Ahx-DOTA- $\left.{ }^{68} \mathrm{Ga}\right) \mathrm{NH}_{2}$ ]-exendin-4. PGA, Gelofusine, and combination of the 2 significantly reduce renal accumulation of [Lys ${ }^{40}(\mathrm{Ahx}-\mathrm{DOTA}$ $\left.{ }^{68} \mathrm{Ga}\right) \mathrm{NH}_{2}$ ]-exendin-4 (A). At same time, tumor uptake is not affected by PGA or Gelofusine (B). Combination of PGA and Gelofusine is more efficient than PGA and Gelofusine alone. PGA plus Gelofusine pretreated Rip1Tag2 mouse (C) shows $78 \%$ lower kidney uptake than untreated control (D). In both animals, distinct differentiation between tumors and kidneys was not possible. 


\section{DISCUSSION}

GLP-1 receptor imaging is a novel approach for preoperative localization of insulinoma. First clinical studies using ${ }^{111}$ In-labeled GLP-1 receptor agonist $\left[\mathrm{Lys}^{40}(\mathrm{AhX}-\right.$ DOTA- $\left.{ }^{111} \mathrm{In}\right) \mathrm{NH}_{2}$ ]-exendin-4 detected 6 of 6 benign insulinomas (20). The present study describes new ${ }^{68} \mathrm{Ga}-$ and 99mTc-labeled GLP-1 receptor agonists for PET/CT and SPECT/CT, respectively. The pharmacokinetics of the new compounds were compared with our gold standard [Lys ${ }^{40}$ (Ahx-DOTA- ${ }^{111} \mathrm{In}$ ) $\mathrm{NH}_{2}$ ]-exendin-4.

[Lys ${ }^{40}\left(\right.$ Ahx-DOTA- $\left.{ }^{68} \mathrm{Ga}\right) \mathrm{NH}_{2}$ ]-exendin-4 showed not only a fast, high, and specific uptake in the tumors but also a high tumor-to-background ratio. The high kidney uptake was significantly reduced by the administration of PGA, Gelofusine, or the combination of the 2 substances. In our mouse model, there was no significant difference in the biodistribution of $\left[\mathrm{Lys}^{40}\left(\mathrm{Ahx}-\mathrm{DOTA}-{ }^{68} \mathrm{Ga}\right) \mathrm{NH}_{2}\right]$-exendin-4 and $\left[\mathrm{Lys}^{40}\left(\mathrm{Ahx}-\mathrm{DOTA}-{ }^{111} \mathrm{In}\right) \mathrm{NH}_{2}\right]$-exendin-4. Accordingly, ${ }^{111}$ In- and ${ }^{68}$ Ga-labeled exendin-4 may show similar biodistributions and pharmacokinetics in humans. Two small tumors (1.5 and $2.3 \mathrm{~mm}$ ) in the mouse pancreas were visualized using the same hybrid PET/CT camera as used for patients, showing the high potential of $\left[\mathrm{Lys}^{40}(\mathrm{Ahx}-\right.$ DOTA- $\left.{ }^{68} \mathrm{Ga}\right) \mathrm{NH}_{2}$ ]-exendin-4 PET in the detection of small tumors. PET has a higher sensitivity and spatial resolution than SPECT (29). This might be important because a high spatial resolution may facilitate the delineation of tumors and kidneys, especially at early time points after injection of the tracer. In a previous clinical study, we showed that the relatively low spatial resolution of $\left[\mathrm{Lys}^{40}\right.$ (AhxDOTA- $\left.{ }^{111} \mathrm{In}\right) \mathrm{NH}_{2}$ ]-exendin-4 SPECT is a relevant limitation of the method. In 2 of 6 patients, delineation of the tumor from the kidneys was possible only on late scans obtained more than $3 \mathrm{~d}$ after injection (20). In addition, a high sensitivity in tumor detection is desirable because $90 \%$ of insulinomas are small, with a diameter of less than $2 \mathrm{~cm}$ (30). Recent studies using ${ }^{68} \mathrm{Ga}$-labeled somatostatin receptor agonists showed a high sensitivity in the detection of somatostatin receptor subtype 2-expressing tumors (31-35).

${ }^{68} \mathrm{Ga}$ is a highly suitable positron emitter for PET because it is a generator product with a half-life of 68 min that decays by $89 \%$ through positron emission (36). Importantly, the short half-life of ${ }^{68} \mathrm{Ga}$ will cause lower radiation doses to patients than will $\left[\mathrm{Lys}^{40}(\mathrm{Ahx}-\mathrm{DO}-\right.$ TA- $\left.{ }^{111} \mathrm{In}\right) \mathrm{NH}_{2}$ ]-exendin-4. In the Rip1Tag2 animal model, [Lys ${ }^{40}$ (Ahx-DOTA- $\left.{ }^{68} \mathrm{Ga}\right) \mathrm{NH}_{2}$ ]-exendin-4 showed rapid blood clearance and fast target localization, making shortlived $\left[\right.$ Lys $^{40}$ (Ahx-DOTA- $\left.{ }^{68} \mathrm{Ga}\right) \mathrm{NH}_{2}$ ]-exendin-4 a suitable PET tracer for GLP-1 insulinoma imaging.

Overexpression of GLP-1 receptors not only on insulinoma cells but also on pancreatic $\beta$-cells provides a further application of GLP-1 receptor imaging (37-39). Brom et al. evaluated noninvasive $\beta$-cell SPECT using the GLP-1 receptor agonist ${ }^{111}$ In-DTPA-exendin-3. They found a sig- nificant correlation between ${ }^{111}$ In-DTPA-exendin-3 uptake and $\beta$-cell mass in rats (40). GLP-1 receptor imaging is a noninvasive method with the potential to monitor the $\beta$-cell mass during the course of diabetes development and during antidiabetic treatment. Furthermore, the method might be used for noninvasive monitoring of islet cell graft survival after transplantation.

SPECT or SPECT/CT with ${ }^{99 \mathrm{~m}}$ Tc-labeled exendin-4 is an alternative approach to GLP-1 receptor imaging with ${ }^{111} \mathrm{In}$. The estimated effective dose of [Lys ${ }^{40}$ (Ahx-HYNIC- ${ }^{99 m} \mathrm{Tc}$ / EDDA) $\mathrm{NH}_{2}$ ]-exendin- 4 is more than 40 times less than that of its ${ }^{111}$ In-labeled congener compound because of the low energy and short physical half-life of ${ }^{99 \mathrm{~m}} \mathrm{Tc}$ and the significantly lower tumor and organ uptake of [Lys ${ }^{40}$ (Ahx-HYNIC-99mTc/EDDA) $\mathrm{NH}_{2}$ ]-exendin-4, compared with $\left[\right.$ Lys $^{40}$ (Ahx-DOTA- $\left.\left.{ }^{111} \mathrm{In}\right) \mathrm{NH}_{2}\right]$-exendin-4. These data can be explained by the significantly less efficient internalization. Regression analysis showed a significant correlation between the rate of internalization and the uptake in the tumor at $4 \mathrm{~h}$ after injection of the respective radiopeptide (Fig. 4). Despite lower tumor uptake, [Lys ${ }^{40}$ (Ahx-HYNIC-99mTc/EDDA) $\mathrm{NH}_{2}$ ]-exendin-4 multipinhole SPECT detected multiple small tumors (diameter, 1.0-3.2 $\mathrm{mm}$ ) in the pancreas and is therefore a promising candidate for clinical GLP-1 receptor imaging studies.

In addition, ${ }^{99 \mathrm{~m}} \mathrm{Tc}$ is a radionuclide suitable for detection with a $\gamma$-probe. Hence, intraoperative localization of insulinomas using a normal or endoscopic $\gamma$-probe might be an additional clinical application of $\left[\mathrm{Lys}^{40}(\mathrm{Ahx}-\mathrm{HY}-\right.$ NIC- ${ }^{99 m}$ Tc/EDDA)NH ${ }_{2}$ ]-exendin-4.

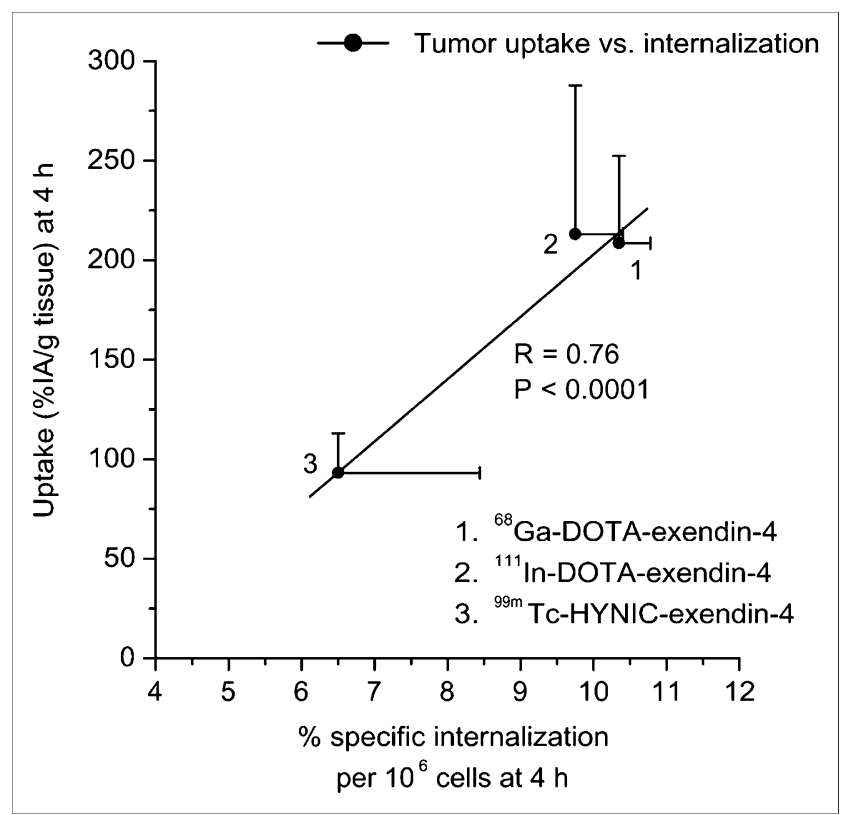

FIGURE 4. Correlation of tumor uptake (\%IA/g of tissue) and internalization (percentage of specific internalized $/ 10^{6}$ cells) at $4 \mathrm{~h}$. Each data point shows mean tumor uptake \pm $\mathrm{SD}$ and mean internalization $\pm \mathrm{SD}$. 


\section{CONCLUSION}

These promising pharmacokinetic and imaging data show that $\left[\mathrm{Lys}^{40}\left(\mathrm{Ahx}-\mathrm{DOTA}-{ }^{68} \mathrm{Ga}\right) \mathrm{NH}_{2}\right]$-exendin-4 and $\left[\mathrm{Lys}^{40}\right.$ (Ahx-HYNIC-99mTc/EDDA) $\mathrm{NH}_{2}$ ]-exendin-4 are suitable candidates for clinical GLP-1 receptor imaging studies. PET/CT with $\left[\mathrm{Lys}^{40}\left(\mathrm{Ahx}-\mathrm{DOTA}-{ }^{68} \mathrm{Ga}\right) \mathrm{NH}_{2}\right]$-exendin-4 will possibly localize small insulinomas at early time points after injection, and SPECT/CT with [Lys ${ }^{40}$ (Ahx-HYNIC- ${ }^{99 m}$ Tc/EDDA) $\mathrm{NH}_{2}$ ]-exendin-4 will potentially increase the availability of the method.

\section{ACKNOWLEDGMENTS}

We thank Novartis Pharma for analytical assistance and Dr. Daniel Storch, Dr. Andreas Baumann, Dr. Stefan Kneifel, Sybille Tschumi, Edith Rauber, and Roland Jost for their expert technical help. During the review process of this manuscript, a paper was published by Brom et al. (41) on the ${ }^{68} \mathrm{Ga}$ labeling of a similar peptide showing promising results in a tumor xenograft model. This work was supported in part by Oncosuisse grant OCS-01778-08-2005, grants from the Novartis Foundation and Swiss National Science Foundation (PASMP3-123269, 320000-118333, and COST D38), and a grant from the Yde Foundation.

\section{REFERENCES}

1. Reubi JC. Peptide receptors as molecular targets for cancer diagnosis and therapy. Endocr Rev. 2003;24:389-427.

2. Schottelius M, Wester HJ. Molecular imaging targeting peptide receptors. Methods. 2009;48:161-177.

3. Ricke J, Klose KJ, Mignon M, Oberg K, Wiedenmann B. Standardisation of imaging in neuroendocrine tumours: results of a European delphi process. Eur J Radiol. 2001;37:8-17.

4. Krenning EP, Kwekkeboom DJ, Bakker WH, et al. Somatostatin receptor scintigraphy with [ $\left.{ }^{111} \mathrm{In}-\mathrm{DTPA}-\mathrm{D}-\mathrm{Phe}^{1}\right]$ - and $\left[{ }^{123} \mathrm{I}-\mathrm{Tyr}^{3}\right]$-octreotide: the Rotterdam experience with more than 1000 patients. Eur J Nucl Med. 1993;20:716-731.

5. Lebtahi R, Cadiot G, Sarda L, et al. Clinical impact of somatostatin receptor scintigraphy in the management of patients with neuroendocrine gastroenteropancreatic tumors. J Nucl Med. 1997;38:853-858.

6. Modlin IM, Tang LH. Approaches to the diagnosis of gut neuroendocrine tumors: the last word (today). Gastroenterology. 1997;112:583-590.

7. Zimmer T, Stolzel U, Bader M, et al. Endoscopic ultrasonography and somatostatin receptor scintigraphy in the preoperative localisation of insulinomas and gastrinomas. Gut. 1996;39:562-568.

8. Reubi JC, Waser B. Concomitant expression of several peptide receptors in neuroendocrine tumours: molecular basis for in vivo multireceptor tumour targeting. Eur J Nucl Med Mol Imaging. 2003;30:781-793.

9. Chatziioannou A, Kehagias D, Mourikis D, et al. Imaging and localization of pancreatic insulinomas. Clin Imaging. 2001;25:275-283.

10. Ramage JK, Davies AH, Ardill J, et al. Guidelines for the management of gastroenteropancreatic neuroendocrine (including carcinoid) tumours. Gut. 2005;54(suppl 4):iv1-iv16.

11. Kauhanen S, Seppanen M, Minn H, et al. Fluorine-18-L-dihydroxyphenylalanine $\left({ }^{18} \mathrm{~F}\right.$-DOPA) positron emission tomography as a tool to localize an insulinoma or $\beta$-cell hyperplasia in adult patients. J Clin Endocrinol Metab. 2007;92: 1237-1244.

12. Tessonnier L, Sebag F, Ghander C, et al. Limited value of ${ }^{18} \mathrm{~F}-\mathrm{F}$-DOPA PET to localize pancreatic insulin-secreting tumors in adults with hyperinsulinemic hypoglycemia. J Clin Endocrinol Metab. 2010;95:303-307.

13. Wiesli P, Brandle M, Schmid C, et al. Selective arterial calcium stimulation and hepatic venous sampling in the evaluation of hyperinsulinemic hypoglycemia: potential and limitations. J Vasc Interv Radiol. 2004;15:1251-1256.

14. Tucker ON, Crotty PL, Conlon KC. The management of insulinoma. Br J Surg. 2006;93:264-275.
15. Gotthardt M, Fischer M, Naeher I, et al. Use of the incretin hormone glucagonlike peptide-1 (GLP-1) for the detection of insulinomas: initial experimental results. Eur J Nucl Med Mol Imaging. 2002;29:597-606.

16. Gotthardt M, Lalyko G, van Eerd-Vismale J, et al. A new technique for in vivo imaging of specific GLP-1 binding sites: first results in small rodents. Regul Pept. 2006; 137:162-167.

17. Wild D, Behe M, Wicki A, et al. [Lys ${ }^{40}\left(\right.$ Ahx-DTPA- $\left.\left.{ }^{111} \mathrm{In}\right) \mathrm{NH}_{2}\right]$ exendin-4, a very promising ligand for glucagon-like peptide-1 (GLP-1) receptor targeting. J Nucl Med. 2006;47:2025-2033.

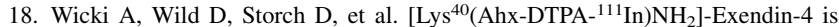
a highly efficient radiotherapeutic for glucagon-like peptide-1 receptor-targeted therapy for insulinoma. Clin Cancer Res. 2007;13:3696-3705.

19. Wild D, Macke H, Christ E, Gloor B, Reubi JC. Glucagon-like peptide 1-receptor scans to localize occult insulinomas. N Engl J Med. 2008;359:766-768.

20. Christ E, Wild D, Forrer F, et al. Glucagon-like peptide-1 receptor imaging for localization of insulinomas. J Clin Endocrinol Metab. 2009;94:4398-4405.

21. IUPAC-IUB Commission on Biochemical Nomenclature (CBN). Symbols for amino-acid derivatives and peptides, recommendations 1971. Eur J Biochem. 1972;27:201-207.

22. Schramm NU, Ebel G, Engeland U, Schurrat T, Behe M, Behr TM. Highresolution SPECT using multi-pinhole collimation. IEEE Trans Nucl Sci. 2003; $50: 315-320$

23. Stabin MG, Sparks RB, Crowe E. OLINDA/EXM: the second-generation personal computer software for internal dose assessment in nuclear medicine. J Nucl Med. 2005;46:1023-1027.

24. Zhernosekov KP, Filosofov DV, Baum RP, et al. Processing of generatorproduced ${ }^{68} \mathrm{Ga}$ for medical application. $J$ Nucl Med. 2007;48:1741-1748.

25. Hanahan D. Heritable formation of pancreatic beta-cell tumours in transgenic mice expressing recombinant insulin/simian virus 40 oncogenes. Nature. 1985; 315:115-122.

26. Sgouros G. Bone marrow dosimetry for radioimmunotherapy: theoretical considerations. J Nucl Med. 1993;34:689-694.

27. International Commission on Radiological Protection (ICRP). Recommendations of the International Commission on Radiological Protection. ICRP publication 60. Oxford, U.K.: Pergamon Press; 1991.

28. Gotthardt M, van Eerd-Vismale J, Oyen WJ, et al. Indication for different mechanisms of kidney uptake of radiolabeled peptides. J Nucl Med. 2007;48: 596-601.

29. Martin WH, Delbeke D, Patton JA, Sandler MP. Detection of malignancies with SPECT versus PET, with 2-[fluorine-18]fluoro-2-deoxy-D-glucose. Radiology. 1996;198:225-231

30. Gouya H, Vignaux O, Augui J, et al. CT, endoscopic sonography, and a combined protocol for preoperative evaluation of pancreatic insulinomas. AJR. 2003;181: 987-992.

31. Antunes P, Ginj M, Zhang H, et al. Are radiogallium-labelled DOTA-conjugated somatostatin analogues superior to those labelled with other radiometals? Eur J Nucl Med Mol Imaging. 2007;34:982-993.

32. Gabriel M, Decristoforo C, Kendler D, et al. ${ }^{68} \mathrm{Ga}$-DOTA-Tyr ${ }^{3}$-octreotide PET in neuroendocrine tumors: comparison with somatostatin receptor scintigraphy and CT. J Nucl Med. 2007;48:508-518.

33. Kayani I, Bomanji JB, Groves A, et al. Functional imaging of neuroendocrine tumors with combined PET/CT using ${ }^{68} \mathrm{Ga}$-DOTATATE (DOTA-DPhe ${ }^{1}, \mathrm{Tyr}^{3}$ octreotate) and ${ }^{18}$ F-FDG. Cancer. 2008;112:2447-2455.

34. Ambrosini V, Tomassetti P, Castellucci P, et al. Comparison between ${ }^{68} \mathrm{Ga}$-DOTANOC and ${ }^{18} \mathrm{~F}$-DOPA PET for the detection of gastro-entero-pancreatic and lung neuro-endocrine tumours. Eur J Nucl Med Mol Imaging. 2008;35:1431-1438.

35. Buchmann I, Henze M, Engelbrecht S, et al. Comparison of ${ }^{68}$ Ga-DOTATOC PET and ${ }^{111}$ In-DTPAOC (Octreoscan) SPECT in patients with neuroendocrine tumours. Eur J Nucl Med Mol Imaging. 2007;34:1617-1626.

36. Maecke HR, Hofmann M, Haberkorn U. ${ }^{68}$ Ga-labeled peptides in tumor imaging. J Nucl Med. 2005;46(suppl 1):172S-178S.

37. Kieffer TJ, Habener JF. The glucagon-like peptides. Endocr Rev. 1999;20:876-913.

38. Korner M, Stockli M, Waser B, Reubi JC. GLP-1 receptor expression in human tumors and human normal tissues: potential for in vivo targeting. J Nucl Med. 2007;48:736-743.

39. Tornehave D, Kristensen P, Romer J, Knudsen LB, Heller RS. Expression of the GLP-1 receptor in mouse, rat, and human pancreas. J Histochem Cytochem. 2008;56:841-851.

40. Brom M, Baumeister P, Melis M, et al. Determination of the $\beta$-cell mass by SPECT imaging with In-111-DTPA-exendin-3 in rats [abstract]. $J$ Nucl Med. 2009;50(suppl 2):147.

41. Brom M, Oyen WJ, Joosten L, Gotthardt M, Boerman OC. ${ }^{68}$ Ga-labelled exendin-3, a new agent for the detection of insulinomas with PET. Eur J Nucl Med Mol Imaging. January 29, 2010 [Epub ahead of print]. 